ADRIAN PRAETZELLIS

\section{Introduction: Why Every Archaeologist Should Tell Stories Once in a While}

Every archaeological site has its own character that is created by the structure, content, and history of the site itself - the "hard" data-and by what the experienced excavator sees in it, what some used to sneer at as mere intuition.

"The excavator placed her units intuitively" used to be, and perhaps still is, another way of saying that she made a stab in the dark. Many years in the field and an intimate understanding of her research area might be dismissed at a stroke, because our archaeologist did not use a table of random numbers to decide where to dig her holes. Guesswork is not what we scientists would like to be known for, and that is all well and good. After all, if archaeological interpretation is no more than opinion, then the speculations of supermarket tabloid writers would be as valid as those of the trained professional in matters archaeological. And that would put most of us out of work. However, as Dan Mouer (1997, pers. comm.) so eloquently put it, there is more than a simple dichotomy between "Hemplemania" and the folk who think that "green men from Mars drew lines on the Nazca Plain." The fact is, an experienced archaeologist will have insights about their site that he or she cannot entirely justify on the basis of the "data." This character is what I mean by the site's story.

It is the site's story in the sense that the story emerges from the site. But this is not to say that some specific story lurks within the soil and artifacts waiting to be freed by the archaeologist. On the contrary. The site contains many potential stories, but every one is a product of the archaeological imagination that pulls together historical and archaeological facts into an interpretation that is more than the sum of the parts of which it is made and more than its excavator can document in the usual way.
When an archaeologist writes up an archaeological excavation, he spends most of his time doing the thousand little fiddly things that will document what he did, what he found, and sometimes even what he thinks it means. Having done all that and knowing the site pretty much backwards and forwards, an excavator will get to the point where an idea has developed in mind of what the site is really about. Sometimes, for me, it will hinge on a single artifact; or a combination of what I know about the history of the people who lived there and something they left behind that is particularly evocative. It is a very personal thing, and it will not usually find its way into the report because I feel that it is too impressionistic. It just ain't Science.

By the same token, when we attend professional meetings to confer, consult, and generally hobnob with our colleagues, we are very concerned to say no more than what we intend in our presentations. We carefully qualify almost every statement for fear that someone will selfrighteously jump all over us. Again, this is not altogether bad; for without basic methodological rigor, we have no more claim to authority than the man or woman on the street. The legacy of the New Archaeology is that we must put our reasoning on the table where it can be picked at, sized up, used, or discounted. The liberating aspect of modern - or post-modern - archaeology, however, is that by throwing positivism out of the window, we have allowed ourselves the freedom to take on an interpretive approach that does not require us to come up with answers to the big questions, those "questions that count."

Of course, there is a danger that stories told by an archaeologist may be a mere reflection of the teller, rather than of the historical context that he or she purports to interpret. One has only to read Neil Asher Silberman's (1989) Between Past and Present to see that archaeologists' stories can have deadly implications. Or archaeology may merge with fiction and psychological autobiography. This is not necessarily a bad thing, but is probably not an activity that merits public funding. 
But worst of all, the stories we tell may become tedious. It is clear that one must ask questions in order to formulate an interpretation; and that the creation of a question presupposes a model (read "story") about the way in which some aspect of the world works. By investing heavily in a model, the archaeologist may find himself merely telling the same story over and over. The tales told, for example, by archaeologists devoted to critical theory may be "true" in that they reflect a portion of the historical reality of a time and place, but they lose their power through constant repetition. Every site becomes merely another opportunity to identify one particular historical process at work-and we all know which that is. In short, every site has the same story to tell. In the case of the evolution and cultural implications of capitalism, the story is important enough to tell time and again. I suggest, however, that one of the benefits of storytelling is that, if we wish, it can free us to chose between either presenting the world through a lens of some theoretical model, or following our individual imaginations. In one sense, all archaeological interpretation can be viewed as storytelling. In his forthcoming book, Digging Sites and Telling Stories, Dan Mouer ([1998]) notes that a colleague once objected by saying, "We can't just dig sites and tell stories." Dan suggests that we really cannot do anything else, and goes on to say, "The question is: Do we tell good stories? And do we tell them well?"

In Kent Flannery's (1982) classic address "The Golden Marshalltown," he spoke of a character who, finding himself unable to actually do archaeology, whipped up a new paradigm like a batch of scrambled eggs. Never again did he have to grapple with the meaning of excavated data or put together a research design that would actually be useful in interpreting what he found. None of our storytellers would suggest that their mode should replace old fashioned archaeological interpretation. Neither do they propose storytelling as some kind of postmodern "Archaeology for Dummies" for those who just cannot be bothered to do it properly. That would be analogous to the position taken by my 14-year-old son who tells me that he does not have to spell correctly because the word-processing program will take care of it.

Mary Praetzellis, who organized this session, chose the contributors because they have paid their dues on-site and have dirt under their fingernails (in some cases quite literally, and I have spoken to them about that in private). They are people who have spent years doing the donkey work of practical archaeology and writing their reports. They are not looking for shortcuts, just an additional way of explaining what their sites are about. In short, Mary's goal was to give our colleagues a venue where they could indulge themselves without having to qualify every other word or to fight to keep the audience awake. And it worked. In 1997 at The Society for Historical Archaeology Conference on Historical and Underwater Archaeology, held in Corpus Christi, my co-performer, Anmarie Medin, and I successfully performed a feat rarely attempted at a meeting of archaeologists: we spoke for 15 minutes without using a single slide.

Will the storytellers ever know if the motivations that they have assigned to their characters are authentic? Of course not. Would these people, long dead, approve of what we have to say of them, or for them? Frankly, I have no idea what the New England businessman-attorney Josiah Gallup would think of the words that I have impudently put into his mouth. Fortunately for us storytellers, none of our subjects are in a position to argue with us or to file charges of slander. So, I invite you to disengage your skepticism and, temporarily at least, accept the nottoo-serious motto of this session: "I'd rather be wrong in an interesting way, than right and boring" (James Deetz, ca. 1981, pers. comm.).

And now, on with the show. 


\section{REFERENCES}

FLANNERY, KeNT

1982 The Golden Marshalltown. A Parable of the Archaeology of the 1980s. American Anthropologist 84:265-278.

MOUER, DAN

[1998] Digging Sites and Telling Stories: Essays in Interpretive Historical Archaeology. Plenum, New York.
Silberman, NeIl Asher

1989 Between Past and Present: Archaeology, Ideology, and Nationalism in the Modern Middle East. Anchor, New York.

\author{
Adrian Praetzellis \\ DEPARTMENT OF ANTHROPOLOGY \\ Anthropological Studies Center \\ SONOMA STATE University \\ ROHNERT PARK, CA 94928
}

